\title{
IDENTIFICATION OF A BACTERIO-OPSIN SPECIES WITH A N-TERMINALLY EXTENDED AMINO ACID SEQUENCE
}

\author{
Hans-Georg DELLWEG and Manfred SUMPER \\ Institut für Biochemie, Genetik und Mikrobiologie, Lehrstuhl Biochemie 1, Universität Regensburg, Universitätsstraße 31, \\ 8400 Regensburg, FRG
}

Received 9 June 1980

\section{Introduction}

Halobacterium halobium, when induced for purple membrane production, synthesizes the integral membrane protein bacterio-opsin at a much higher rate than other membrane proteins [1]. Bacterio-opsin is therefore an attractive model for studying the problem of synthesis of intrinsic membrane proteins [2].

Protein synthesis of bacterio-opsin and some other membrane proteins in vivo is selectively disturbed when $\mathrm{Mg}^{2+}$ are removed from the medium, whereas no effect on the synthesis of cytoplasmic proteins can be observed. Re-addition of $\mathrm{Mg}^{2+}$ to the cell suspension reconstitutes an almost normal membrane protein pattern. Instead of bacterio-opsin however, a protein species with a slightly higher apparent molecular weight appears, which is referred to as 27000 $M_{\mathrm{r}}$ protein [3].

Here we show that the $27000 M_{\mathrm{r}}$ protein is a bacterio-opsin molecule which is elongated by an additional peptide at the $\mathrm{N}$-terminus. The $\mathrm{N}$-terminal amino acid sequence of the protein was determined up to position 5 by manual Edman radiosequencing. We found the sequence:

$\mathrm{H}_{2} \mathrm{~N}-$ Met-Leu- ? -Leu-Leu-(Leu)-... .

\section{Materials and methods}

\subsection{Strain and culture conditions}

Halobacterium halobium $\mathbf{R}_{1} \mathbf{M}_{1}$ [4] was used for all experiments and grown in a peptone medium [5] as in [3].

\subsection{Radioactive labelling of bacterio-opsin}

The labelling of bacterio-opsin with radioactive amino acids is described in [3].

\subsection{Radioactive labelling and isolation of $27000 \mathrm{M}_{r}$ protein}

Halobacteria were converted into spheroplasts as in [3], $\mathrm{MgCl}_{2}$ was then added to the spheroplast suspension $(2 \mathrm{ml})$ to $0.1 \mathrm{~mol} / 1$ final conc. After addition of radioactive amino acids $\left(15 \mu \mathrm{Ci} \mathrm{L}-\left[\mathrm{U}-{ }^{14} \mathrm{C}\right]\right.$. leucine, $350 \mathrm{mCi} / \mathrm{mmol}$ or $50 \mu \mathrm{Ci} \mathrm{L}$-amino acid mixture $\left[\mathrm{U}-{ }^{14} \mathrm{C}\right]$ or $20 \mu \mathrm{Ci} \mathrm{L}-\left[{ }^{35} \mathrm{~S}\right]$ methionine, $500 \mathrm{Ci} /$ mmol) the cells were gently stirred at $37^{\circ} \mathrm{C}$ and illuminated with yellow light (slide projector with an OG $515 \mathrm{~nm}$ cut-off filter) for $60 \mathrm{~min}$.

The cells were lyzed and the membrane fraction, containing $27000 M_{\mathrm{r}}$ protein; was isolated as described for bacterio-opsin [3]. The $27000 M_{\mathrm{r}}$ protein was purified by SDS-polyacrylamide gel electrophoresis on $12 \%$ slab gels [6], localized by autoradiography and recovered by elution. The eluted protein was lyophilized, redissolved in water and SDS removed by precipitation with $\mathrm{KCl}$ [7]. Glycine and other buffer substances were removed by gel filtration on Sephadex G-25.

\subsection{Peptide mapping}

Radioactive proteins mixed with unlabelled bacterio-opsin were dissolved in the smallest possible volume of $70 \%$ formic acid, containing $0.1 \%$ phenol. A 50-fold excess of $\mathrm{BrCN}(\mathrm{w} / \mathrm{w})$, was added and the mixture flushed with nitrogen and kept in the dark at room temperature for $24 \mathrm{~h}$ [8]. The cleavage products were lyophilized, redissolved in $80 \%$ formic acid, containing $0.1 \%$ phenol, and the peptides layered onto a Biogel P 30 column (100-200 mesh; $4 \times 1500 \mathrm{~mm}$ ), and eluted with the formic acid/phenol solvent. Column fractions $(0.4 \mathrm{ml})$ were lyophilized, redissolved in a small volume of $60 \%$ formic acid, and spotted onto silica gel thin-layer chromatography 
plates $(20 \times 20 \mathrm{~cm}$, without fluorescent indicator, Merck), and developed with 2-butanol/water/formic acid ( $70 / 21 / 9$ by vol.). The peptides were visualized with Fluram [9], and radioactive fragments located by fluorography [10].

\subsection{Edman sequence analysis}

Radio-sequencing was performed by adding $1 \mathrm{mg}$ myoglobin as protein carrier to $3-5 \times 10^{5} \mathrm{cpm}$ of labelled $27000 M_{\mathrm{r}}$ protein. The samples were manually degraded as in [11]; the extraction and conversion procedures were done as in [12]. Radioactive PTH. amino acids were identified by fluorography of thinlayer chromatograms [13].

\section{Results and discussion}

Rod-shaped halobacteria can be converted into spheres by complexing $\mathrm{Mg}^{2+}$ in the medium with EDTA. These spheroplasts lose the ability to produce bacterio-opsin; however, re-addition of $\mathrm{Mg}^{2+}$ leads to the synthesis of a membrane protein with a slightly higher apparent molecular weight $\left(27000 M_{\mathrm{r}}\right)$ than authentic bacterio-opsin $\left(26000 M_{\mathrm{r}}\right)$ (fig.1).

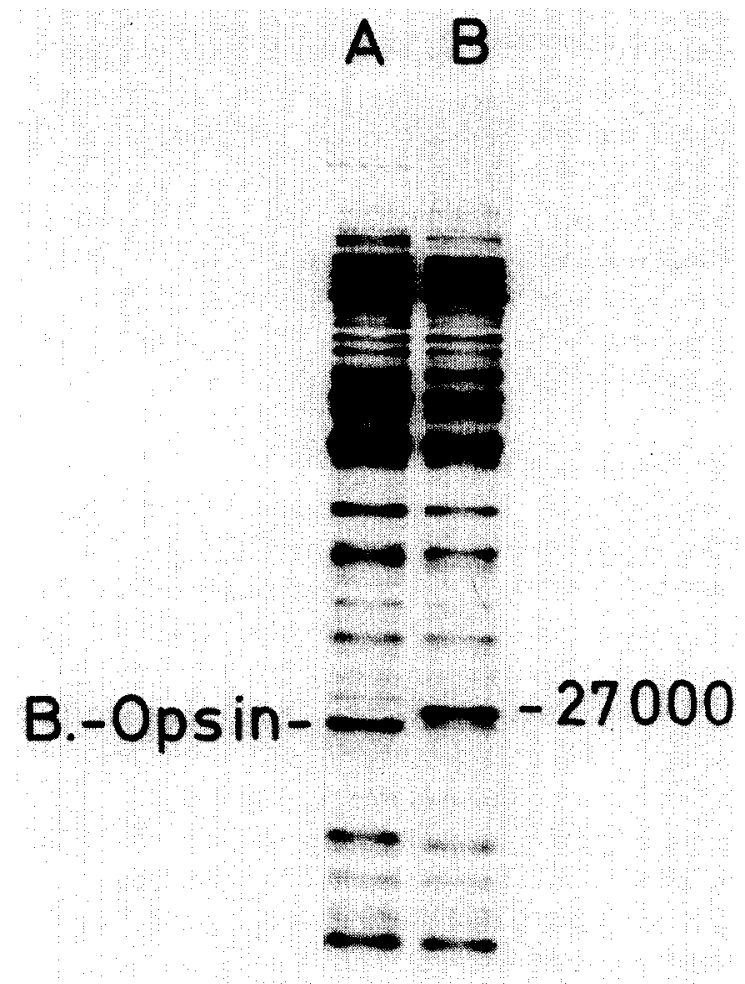

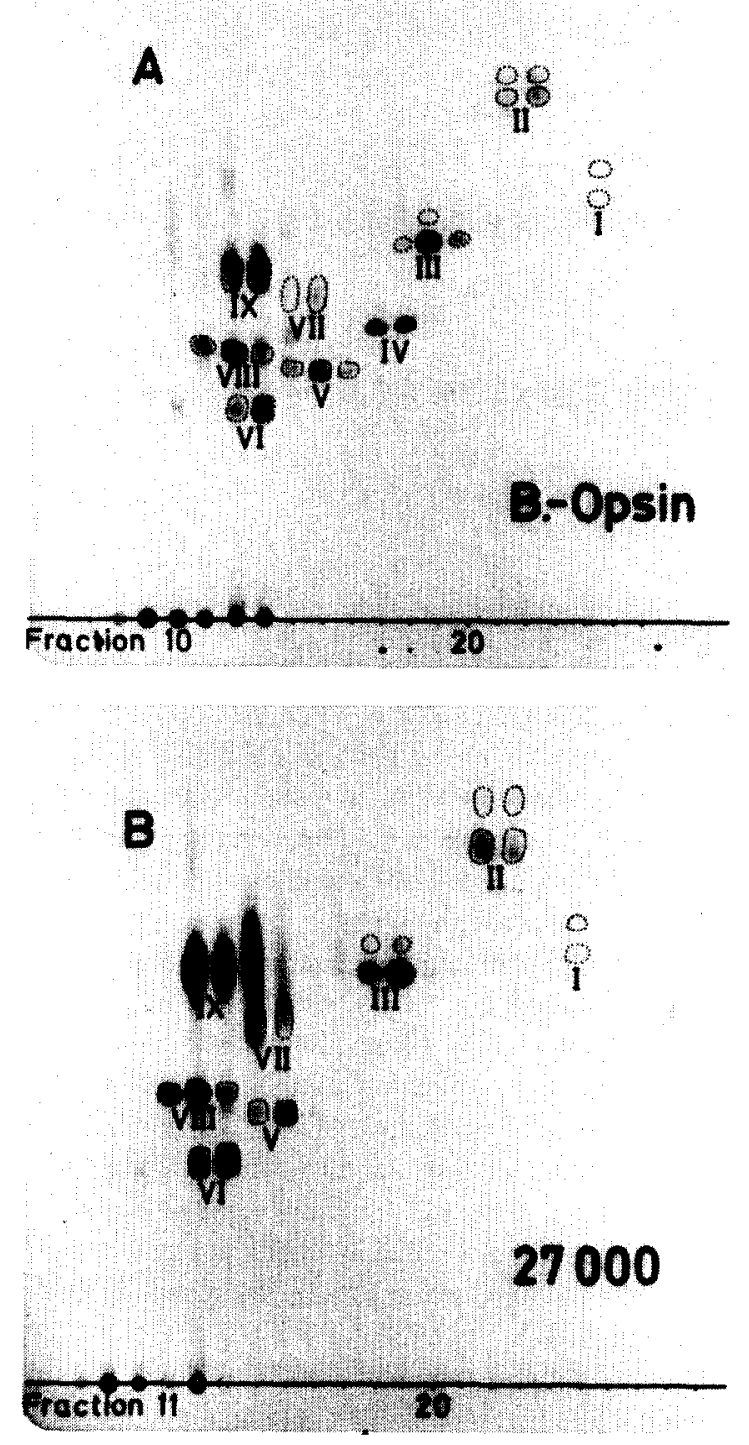

Fig.2. Fluorography of $\mathrm{BrCN}$-peptide maps. $\left[{ }^{14} \mathrm{C}\right]$ Leucinelabelled bacterio-opsin $(\mathrm{A})$ and $\left[{ }^{14} \mathrm{C}\right]$ leucine labelled 27000 $M_{\mathrm{r}}$ protein (B) were mixed with unlabelled bacterio-opsin as protein carrier and cleaved with $\mathrm{BrCN}$. The peptides were separated by gel chromatography on Biogel P 30 . Chromatographic fractions were spotted onto silica gel thin-layer and developed with 2-butanol/water/formic acid $(70 / 21 / 9, \mathrm{v} / \mathrm{v} / \mathrm{v})$. The chromatograms were sprayed with Fluram. The peptides visible under $\mathrm{UV}$, which derive from the carrier bacterioopsin, were marked with dotted lines.

Fig.1. Fluorograms of SDS-polyacrylamide gels after electrophoresis of proteins synthesized by halobacteria before and after conversion to spheroplasts. Pulse labelling (20 $\mathrm{min}$, $20 \mu \mathrm{Ci}\left[{ }^{35} \mathrm{~S}\right]$ methionine) and the preparation of spheroplasts were performed as in section 2. (A) Pratein pattern synthesized by rod-shaped halobacteria; (B) protein pattern synthesized by spheroplasts in the presence of $100 \mathrm{mM} \mathrm{Mg}{ }^{2+}$. 
Table 1

Sequence analysis of water soluble BrCN-peptides of bacterio-opsin

\begin{tabular}{|c|c|c|}
\hline Peptide & Sequence found & $\begin{array}{l}\text { Correlated to the } \\
\text { amino acid sequence }\end{array}$ \\
\hline I & Tyr-Leu- & Peptide $57-60$ \\
\hline II & Leu-Leu-Gly -Tyr-Gly - ... & Peptide $61-68$ \\
\hline III & Gly -Leu-Gly - Thr - Leu - Tyr - Phe $-\ldots$ & Peptide $21-32$ \\
\hline IV & ---------------------- & Peptide $\quad 1-20$ \\
\hline $\mathrm{V}$ & Gly - Val- X -Asp-Pro-Asp-Ala-... & Peptide $33-56$ \\
\hline VI & Val-Leu-Asp-Val - X - Ala-Lys-... & Peptide $210-248$ \\
\hline
\end{tabular}

Bacterio-opsin and $27000 M_{\mathrm{r}}$ protein, labelled with $\left[{ }^{14} \mathrm{C}\right]$ leucine, were isolated by SDS-polyacrylamide gel electrophoresis. The proteins were cleaved with cyanogen bromide and the peptides obtained were separated by chromatography on Biogel P30 followed by thin-layer chromatography on silica gel. Fig.2A shows the peptide pattern obtained from bac- terio-opsin. Using the known amino acid sequence data of bacterio-opsin $[14,15]$, the water soluble peptides I, II, III, V, VI could be identified by manual Edman-degradation. Table 1 summarizes the results obtained. The other peptides, VII, VIII, and IX, were water insoluble and not sequenced. Peptide IV was identified as the blocked $\mathrm{N}$-terminal cyanogen bromide
A

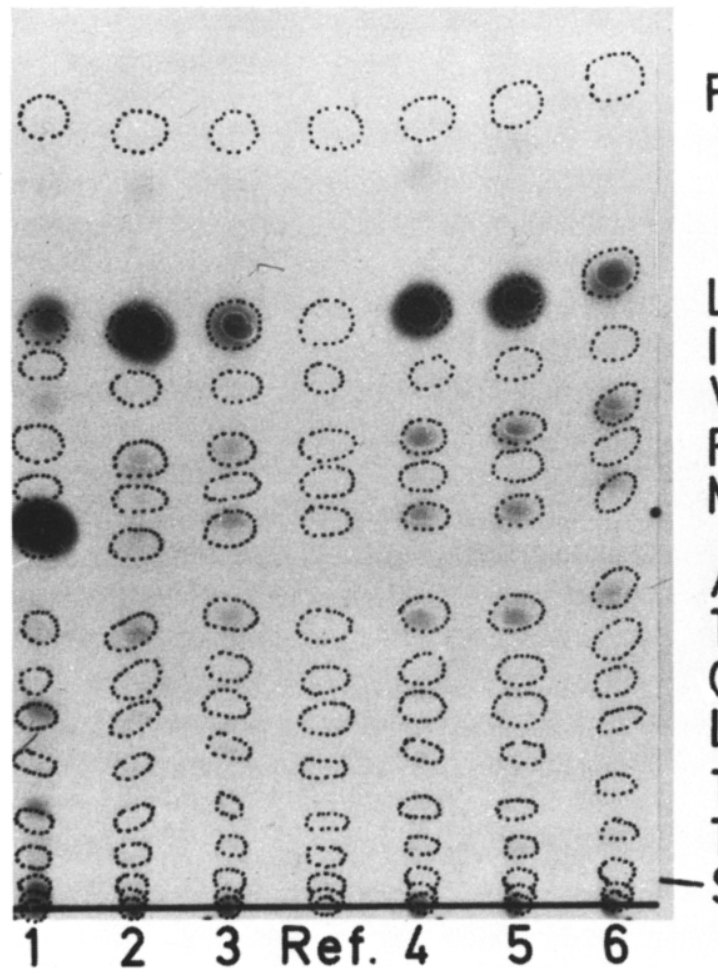

B

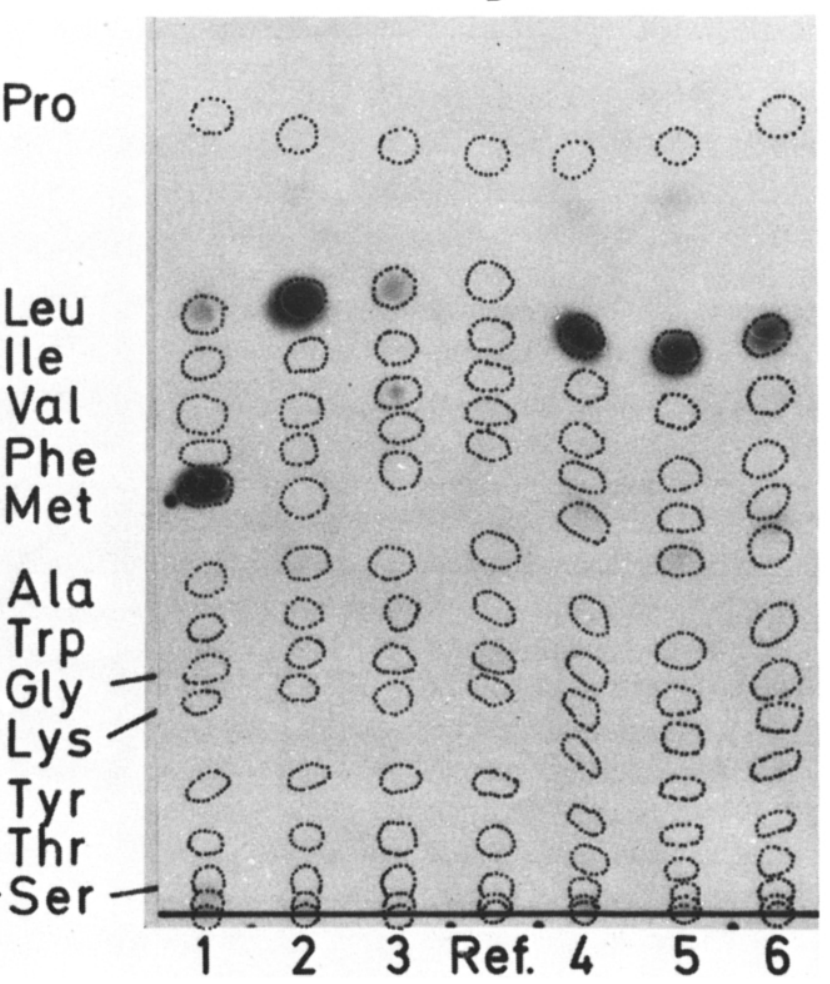

Fig.3. N-terminal sequence of $27000 M_{\mathrm{r}}$ protein. $27000 M_{\mathrm{r}}$ protein labelled with $\left[{ }^{35} \mathrm{~S}\right.$ ]methionine and amino [ $\left.{ }^{14} \mathrm{C}\right] \mathrm{acid}$ mixture (A) and $\left[{ }^{35} \mathrm{~S}\right]$ methionine and $\left[{ }^{14} \mathrm{C}\right]$ leucine (B) was manually degraded by the Edman procedure with myoglobin as protein carrier. PTH derivatives of each step were added to a mixture of unlabelled PTH-amino acids and chromatographed on silica gel thin-layer plates. PTH-amino acid standards were marked with dotted lines, the chromatographs were impregnated with 2-methylnaphtaline/ PPO (1000/4) and fluorographed [10]. Radioactive PTH-amino acids were identified by comparing the fluorograms with the PTHamino acid standards. 
fragment of bacterio-opsin, since:

1. It did not react with Fluram, which requires the presence of free amino groups.

2. Radioactively labelled lysine, tyrosine and valine could not be incorporated into peptide IV; the known sequence data show this peptide to lack these amino acids (as well as Ser, Phe, Asx). No other $\mathrm{BrCN}$ peptide lacks this combination of amino acids.

3. The amino acid analysis of purified peptide IV was in good agreement with the known composition of the N-terminal peptide.

Fig. $2 B$ shows the peptide pattern of $27000 M_{\mathrm{r}}$ protein. It exhibits the same peptides as bacterio-opsin, except peptide IV is missing and a new radioactive peptide appears near peptide IX.

In contrast to the bacterio-opsin polypeptide chain, in which the N-terminus is blocked by a pyroglutamyl residue [18], the $27000 M_{\mathrm{r}}$ protein released PTHmethionine in an Edman degradation experiment. To characterize the $\mathrm{N}$-terminal amino acid sequence of $27000 M_{\mathrm{r}}$, the protein was labelled with various radioactive amino acids, isolated in microquantities by SDS-polyacrylamide gel electrophoresis, and subjected to manual Edman degradation. Fig.3A shows the fluorography of PTH-amino acids of $27000 \mathrm{Mr}_{\mathrm{r}}$ protein labelled with an amino $\left[{ }^{14} \mathrm{C}\right]$ acid mixture supplemented with $\left[{ }^{35}\right.$ S] methionine. Radioactive PTHMet is detected in step 1, while radioactive PTH-Leu is found in step 2,4,5 and with low yield in step 6 . This sequence is confirmed by Edman degradation of $27000 M_{\mathrm{r}}$ protein, labelled only with $\left[{ }^{35}\right.$ S]Met and $\left[{ }^{14} \mathrm{C}\right]$ Leu (fig.3B).

Due to the manual degradation method, much protein was lost during the extraction procedures. Therefore it was possible to analyze the sequence only up to position 5. At step 3, no radioactive amino acid was identified, but the analysis of $27000 M_{\mathrm{r}}$ protein labelled with the amino $\left[{ }^{14} \mathrm{C}\right]$ acid mixture showed that $\left[{ }^{14} \mathrm{C}\right] \mathrm{Asp},\left[{ }^{14} \mathrm{C}\right] \mathrm{Glu},\left[{ }^{14} \mathrm{C}\right] \mathrm{Gly}$ and $\left[{ }^{14} \mathrm{C}\right] \mathrm{Tyr}$ were not or were very poorly incorporated. Furthermore, the amino $\left[{ }^{14} \mathrm{C}\right]$ acid mixture did not contain $\left[{ }^{14} \mathrm{C}\right]$ Asn, $\left[{ }^{14} \mathrm{C}\right] \mathrm{GIn},\left[{ }^{14} \mathrm{C}\right] \mathrm{Cys}$ and $\left[{ }^{14} \mathrm{C}\right] \mathrm{Trp}$ thus these amino acids would never be identified by this type of labelling experiment.

Our experiments show that the $27000 M_{\mathrm{r}}$ protein is a bacterio-opsin species with an additional (hydrophobic- $\mathrm{N}$-terminal peptide. This indicates that at least one protein processing step is necessary during the biosynthesis and integration of this intrinsic mem- brane protein.

The proteolytic removal of an $\mathrm{N}$-terminal peptide during membrane incorporation has been reported for several membrane proteins, for instance $E$. coli lipoprotein [17] and M 13 coat protein [18], but other membrane proteins are known; for example, staphylococcal $\alpha$-toxin [19], which are incorporated into membranes without a proteolytic step.

\section{Acknowledgements}

We thank Dr W. Dompert for performing amino acid analysis experiments and Dr Paul Towner for correcting our English. This work was supported by the Deutsche Forschungsgemeinschaft.

\section{References}

[1] Oesterhelt, D. and Stoeckenius, W. (1973) Proc. Natl. Acad. Sci. USA 70, 2853-2857.

[2] Wickner, W. (1979) Ann. Rev. Biochem. 48, $23-45$.

[3] Sumper, M. and Herrmann, G. (1978) Eur. J. Biochem. $89,229-235$.

[4] Milanytch, M. (1973) Diplomarbeit, Universität München.

[5] Oesterhelt, D. and Stoeckenius, W. (1974) Methods Enzymol. 31, 667-678.

[6] Laemmli, U. K. (1970) Nature 227, 680-685.

[7] Van Heyningen, S. (1973) Biochim. Biophys. Acta $328,303-313$.

[9] Gross, E. and Witkop, B. (1961) J. Am. Chem. Soc. $83,1510-1511$.

[9] Imai, K., Boehlen, P., Stein, S. and Udenfriend, S. (1974) Arch. Biochem. Biophys. 161, 161-163.

[10] Bonner, W. M. and Stedman, J. D. (1978) Anal. Binchem. 89, 247-256.

[11] Platt, T., Files, J. G. and Weber, K. (1973) J. Biol. Chem. 248, 110-121.

[12] Kagamiyama, H., Wada, H., Matsubara, H. and Snell, E. (1972) I. Biol. Chem. 247, $1571-1575$.

[13] Laursen, R. A. (1971) Eur. J. Biochem. 20, 89-102.

[14] Ovchinnikov, Yu. A., Abdulaev, N. G., Feigina, M. Yu., Kiselev, A. V. and Lobanov, N. A. (1979) FEBS Lett. $100,219-224$.

[15] Khorana, H. G., Gerber, G. E., Herlihy, W. C., Gray, C. P., Anderegg, R. J., Nihei, K. and Biemann, K. (1979) Proc. Natl. Acad. Sci. USA 76, 5046-5050.

[16] Ovchinnikov, Yu. A., Abdulaev, N. G., Feigina, M. Yu., Kiselev, A. V. and Lobanov, N. A. (1977) FEBS Lett. $84,1-4$.

[17] Inouye, S., Wang, S., Sekizawa, J., Halegoua, S. and Inouye, M. (1977) Proc. Natl. Acad. Sci. USA 74, $1004-1008$.

[18] Ito, K., Mandel, G. and Wickner, W. (1979) Proc. Natl. Acad. Sci. USA 76, 1199-1203.

[19] Weissmann, G., Sessa, G. and Bernheimer, A. W. (1966) Science $154,772-774$. 